Paper for NECTAR book, revised dec. 2004

\title{
The spatial consequences of Air transport deregulation : an overview of the French case since 1995
}

\author{
Pierre ZEMBRI \\ Université de Cergy-Pontoise \\ Department of Geography - Research Unit JE 2279 MRTE \\ 33, boulevard du Port \\ F-95011 CERGY-PONTOISE CEDEX \\ E-mail : pierre.zembri@1sh.u-cergy.fr
}

\section{Introduction}

The European Community chose in 1984 a progressive liberalization of air transport, which was accomplished in several stages between 1987 and April 1997. This process does not leave the networks unharmed, as demonstrated by the North-American case since 1978, which has been studied by many authors (Button, 1991 ; Oum, 1990 for instance). Some companies completely disappear, some other ones are strongly restructured, and new operators enter the market on various scales. New strategies of service appear, with in particular the adoption of hub and spokes structures (O'Kelly, 1998). And new companies, based on a radically different economic model, appear with the explicit objective to collect a significant share of market, and their favourite weapon is lower prices and «no frills » service (low cost carriers).

Compared to North America, the European market is characterized by a significant compartmentalization on a national basis. The defence of the flag carrier remains a priority whatever the price should be, as show it the recent examples of the former Swissair (which became Swiss) and of the former Sabena (SN Brussels Airlines). The air traffic itself remains partitioned in its management. Moreover, there are no common rules for the allocation of the capacities (slots) between the various carriers in airports. Even if the deregulation process has been decided on a continental scale, rare are the candidates who have the ambition to operate at this scale while not focusing themselves on a single base in their country of origin.

There is now sufficient time from the beginning of the process to take the measurement of many and deep changes of the domestic networks in Europe, and in particular in France, first domestic market of the Union before the liberalization, developed precociously by a very imaginative company, Air Inter. This article accounts for the first results of a research in progress on the space effects of the air deregulation in France and in Europe. We chose to measure the variation of the accessibility of cities which weren't hosting a major gateway in $1997^{1}$. The development of direct domestic and international links avoiding the major hubs, in particular with neighbouring countries, indeed seems to be a positive (and not envisaged) consequence of this deregulation.

Did cities lose in quantity and of service with the deregulation? What has been the evolution of the panel of destinations directly accessible from a given airport ? Did new hubs appear at the national level and are the « windfall gains » long-lasting for their catchment area ? These questions will initially be addressed to the French cities, and in a later phase to the cities of other neighbouring countries.

We will first focus on strategies of the main actors of the Air transport industry (national, regional companies and newcomers). Then, we will treat the evolution of accessibility of the main French cities in connection with the installation of half-dozen of new régional hubs and the progressive intrusion of low-cost carriers. Lastly, we will wonder whether the current situation is still likely to evolve, by taking into account recent recombinings of the actors play and the development of the high speed train network which widens the field of competition.

\footnotetext{
${ }^{1}$ In the French case, that means that Paris is excluded of the study. In the German case, Francfort should be excluded as well.
} 


\section{A competition weaker than expected on the busiest domestic routes}

This first observation is quite unexpected : a current hypothesis is that newcomers in a market focus the competition on the segments most developed before by the existing companies. As regards domestic air transport, the most frequented lines were at the beginning of the years 1990 a half-dozen of radial connections between Paris and the other main towns being at least $500 \mathrm{~km}$ far from it, the competition of the TGV (French high-speed train) having been appreciable under this distance. These main lines, representing $60 \%$ of the French air traffic, have been the first ones opened to competition in 1995 at a national scale (Paris - Marseille, Paris - Toulouse, Paris - Nice, Paris - Bordeaux, Paris - Strasbourg and Paris - Montpellier).

However, as early as 2000, Air France remains alone on Paris-Strasbourg. A few months later (2001), the failure of the « second pole of competition » around Sair Group results in the return to an almost total monopoly of Air France on these most important routes. The monopoly is complete between january 2003 (end of operations of Air Lib) and june 2003, two new candidates trying from this date to dispute this monopoly (Aeris, EasyJet) but with too few financial margins for the former (in bankruptcy 4 months after the beginning of its operations) and too few slots for the latter. On the other hand of this rather disappointing assessment, competition has been much more active on direct connections avoiding the two parisian airports.

\subsection{Only a few main lines are concerned by competition}

It is a fact that any air passenger from or to Paris can easily feel : rare are the lines where he will have a real alternative between two companies or more. Air France always benefits by its de facto monopoly on the great majority of the radial lines, and its tariffs are definitely higher than those of 1996 (table 1), if we exclude some special offers with restrictions.

\section{Table 1 : The evolution of Air France fares on four main radial lines}

\begin{tabular}{|l|l|l|l|}
\hline Line & One-way fares in 1997 & One-way fares in 2000 & One-way fares in 2003 \\
\hline Paris - Strasbourg & 126 EUR & 171 EUR $(+35,8 \%)$ & 225,36 EUR $(+79,65 \%)$ \\
\hline Paris - Montpellier & 151 EUR & 198 EUR $(+31,1 \%)$ & 254,36 EUR $(+68,45 \%)$ \\
\hline Paris - Toulouse & 145 EUR & 189 EUR $(+30,3 \%)$ & 280,36 EUR $(+93,35 \%)$ \\
\hline Paris - Nice & 165 EUR & nc & 304,36 EUR $(+84,46 \%)$ \\
\hline
\end{tabular}

All prices in current currency (inflation is very weak in this period). The prices in FRF (1997 and 2000) have been translated in euros, following the legal parity: 1 EUR $=6,55957 \mathrm{FRF}$. All the evolutions in \% are calculated from 1997. All taxes included.

The reasons are multiple. The first phase of competition, short but very keen, which happened during the first year, had for consequence the withdrawal of a competitor (Euralair) and the near bankruptcy of three others (Air Liberté, TAT and AOM) which were obliged to open their capital, for the two formers to British Airways and for the latter to the Crédit Lyonnais bank. If newcomers, AOM excepted, had built their strategy of conquest of the market on a price war they couldn't afford for a long time, Air Inter then Air France ${ }^{2}$ reacted by offering more frequent flights. This was possible because the flag carrier had large reserves of slots in Paris airports, where it is still dominant in 2003. The official saturation of the Parisian airports was a good reason to refuse new allocations of slots to newcomers, and there has been no general reallocation ${ }^{3}$. It is necessary to add to these factors the constitution of the intercontinental "hub" of Roissy by Air France, which allowed it to be easily the leader on the pre-routings market by directing more domestic flights towards this platform to which its competitors did not have access.

In 2000, competition on the radial lines was much weaker than in 1997 (table 2). Only the ParisNice route preserved three competitors, four other lines had only two ones and Paris-Strasbourg was becoming again a monopoly of Air France. In December 2003, Air France is the only company

\footnotetext{
${ }^{2}$ The two compagnies merged in 1997. Air Inter was a pure domestic company and Air France was a nearly pure international operator.

${ }^{3}$ The « grandfather's right » is applicable in all French airports.
} 
to operate on three of the six connections and its current competitor begin hardly its operations on the three other lines.

Table 2 : Evolution of the competition on the six « millionnaire » routes in 1996, 2000 et 2003.

\begin{tabular}{|c|c|c|c|}
\hline Routes & Competitors in 1996 & Competitors in 2000 & Competitors in 2003 \\
\hline Paris - Nice & $\begin{array}{l}\text { Air Inter, AOM, Air } \\
\text { Liberté }\end{array}$ & $\begin{array}{l}\text { Air France, AOM, Air } \\
\text { Liberté }\end{array}$ & Air France, EasyJet \\
\hline Paris - Marseille & Air Inter, AOM, TAT & Air France, AOM & Air France, EasyJet \\
\hline Paris - Toulouse & $\begin{array}{l}\text { Air Inter, Air Liberté, } \\
\text { Euralair, TAT }\end{array}$ & Air France, Air Liberté & Air France, EasyJet \\
\hline Paris - Bordeaux & Air Inter, Air Liberté & , Air Liberté & Air Fi \\
\hline Paris - Montpellier & $\begin{array}{l}\text { Air Inter, AOM, Air } \\
\text { Liberté }\end{array}$ & Air France, Air Liberté & Air France \\
\hline Paris - Strasbourg & Air Inter, Air Liberté & Air France & Air France \\
\hline
\end{tabular}

Air France has not been really worried by its competitors on the main lines. They could not compete with the national company in the field of the frequencies and any price war was suicidal because of their financial health, not very flourishing. Between May 2000 and the end of 2001, one could believe that a second French pole was to be created with the announced merging of AOM, Air Liberté and Air Littoral, all new subsidiaries of the Sair Group (head office of Swissair). This competitor would have represented $30 \%$ of the domestic market, a hundred of planes and a total turnover of 1,5 billion euros. But the fall of Swissair involved de facto the dismemberment of this stillborn pole. During 2002, the merging of AOM and Air Liberté under the commercial name Air Lib, then the revival by this new entity of a price war on Paris - Nice, Paris - Toulouse and Paris - Marseille, was something like a last-ditch struggle. In January 2003, the French government put an end to this adventure (the fiscal and social debt of Air Lib represented more than its capital), causing the immediate and definitive disappearance of the company.

While the competition was turning to the advantage of Air France on the main lines, some new networks of interregional and international relations avoiding Paris set up themselves, creating the conditions of a considerable opening of the French provinces towards other territories.

\subsection{New hub and spokes networks permit a real opening of the market and a real competition on interregional and international routes avoiding Paris}

Before the liberalization, it was nearly impossible, flying from a French city to another one, to avoid the transit through Paris. It was the same for the connections between French towns and other countries. Only did a handle of companies known as "of third level" like TAT, Air Vendée or Air Littoral operate some point to point cross-country connections (Tours - Poitiers - Toulouse, Caen - Rennes, Rennes - Brest, Nantes - Toulouse, etc.). On its side, Air Inter had founded gradually a « rendez-vous in Lyon », ancestor of the regional hubs, from which 3 to 4 rotations per working day made it possible to join 8 cities without a compulsory transit by the Parisian platforms in 1993. Seven other direct lines served with a weak frequency ${ }^{4}$, and a certain number of seasonal connections during summer weekends (Lille - Montpellier, Nice - Nantes, Toulon - Lille, etc) were also offered.

Insofar as a large part of the competitors were before the deregulation third level companies (TAT, Air Littoral, Regional Airlines ${ }^{5}$ ), they tended to develop their network starting from the preexistent core of lines, developing régional hubs ${ }^{6}$ in airports where they had been able to develop satisfactory relations with the owners (generally local Chambers of Commerce). Except for TAT

\footnotetext{
${ }^{4}$ Lille - Strasbourg (3 rotations per working day), Marseille - Bordeaux (2 rotations), Lille - Bordeaux, Lille - Nice, Lille - Marseille, Bordeaux - Toulouse, Toulouse - Nice (1 rotation). The lines between Corsica and mainland have not been taken into consideration, due to their special status (they are heavily subsidized).

${ }^{5}$ Formerly Air Vendée.

${ }^{6}$ We mean by « régional hubs » airports concentrating several lines and havint adopted a wave-system structure in the airline flight schedule (Bootsma, 1997).
} 
which rather sought to develop a network centered on Paris while preserving its regional "historical" lines, they developed coherent strategies in order to avoid Parisian platforms and to open up the rest of the country towards Europe. This explains the flowering of new regional hubs, either in central position within the territory (Clermont-Ferrand for Regional Airlines, SaintEtienne for Proteus, or in peripheral position like Montpellier or Nice (Air Littoral).

In parallel, Air France packed considerably from 1997-1998 its interregional direct services by reactivating Lyon's platform and by transforming thereafter various regional airports like Strasbourg, Lille, Bordeaux, Nice and Nantes in as much hubs with 5, 6 and even 7 branches. This strategy of development constituted a true frontal attack against carriers who had chosen to avoid any direct confrontation with the national company on the radial lines. All the actors thus seemed to consider that the most significant potential of development was on this emergent market of small cross-country flows, including thus the one which less knew it, taking into account its usual scale of operation, Air France.

Up to the emergence of secondary hubs of the Air France network, we can consider that competition was only partial, and that there were complementarities between networks. Hubs in central position and peripheral ones could compete only on a limited portion of the territory. Thus, both Regional Airlines and Air Littoral proposed combinations between Bordeaux, Toulouse, Nice, Marseille and Lyon for example. On the other hand, it was difficult for the latter to compete effectively with the former on Bordeaux - Lille or Lyon - Rouen. The progressive integration of the networks in one of the two large national poles in competition radically changed the situation.

\subsection{This situation has obliged Air France to multiply alliances and takeovers in order to remain the master of the market}

Basically, Air France has neither the vocation nor the technical capability to operate small volume lines. These services request small capacity planes, offering less than 100 seats, that the national company does not own. It often has, like Air Inter in its time, charterized or franchised companies of third level like Brit Air or Air Littoral on the less frequented lines. This phenomenon of regular subcontracting has been extended thereafter to some short- and middle-distance international flights of the network Air France: that's today the case on Paris - Hanover, Paris - Nuremberg or Paris - Southampton.

This movement became systematic within the political framework of development of secondary hubs, with a progressive evolution from simple franchising to the entry in the capital of the subcontractors. It is also (even especially) for the "historical" carrier a means of avoiding that the small carriers, which knew how to develop effective hubs and partnerships with alien companies, could be used as "Trojan horse" by potential competitors. The competition, initially animated by British Airways, then more recently by Swissair, gained positions while being ensured of strong partnerships with well established regional companies. Some of the latters developed complex strategies of partnership in order not to be completely dependent on a single major company : Regional Airlines was at the same time (1998) "partner" of Air Liberté and chartered by Air France, while developing partnerships with KLM, Lufthansa, Alitalia, SAS, Iberia. This "multisubjection", which offered to the passengers of the company the choice between five gateways, could pass at the same time for the demonstration of a willingness of independence.

In a very different way from British Airways, which had only developed agreements of partnership with regional companies, revocable at any moment, Air France and Swissair rather preferred subjection, in order to more perennialize their position on the market. The former developed from the very beginning of the liberalization process charter contracts and franchising, before passing to the acquisition of Proteus and the purchase of the majority of the shares (70\%) of Regional Airlines. The latter entered in force on the French domestic market by purchasing blow on blow Air Liberté (which was still operating small lines of the former TAT) and Air Littoral. 
5

Figure 1 :The recombining of the market from 1998 to the end of 2003.

\section{Situation in 1998}

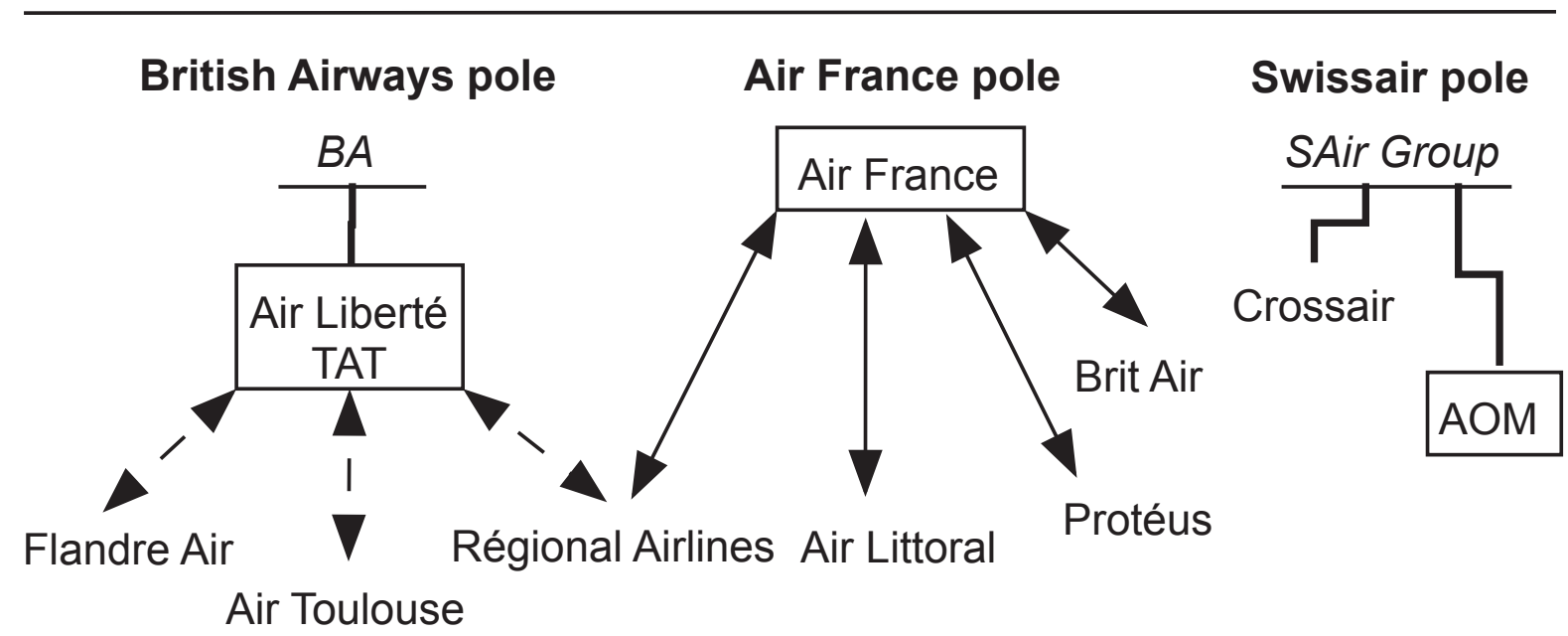

Situation in $\mathbf{2 0 0 0}$

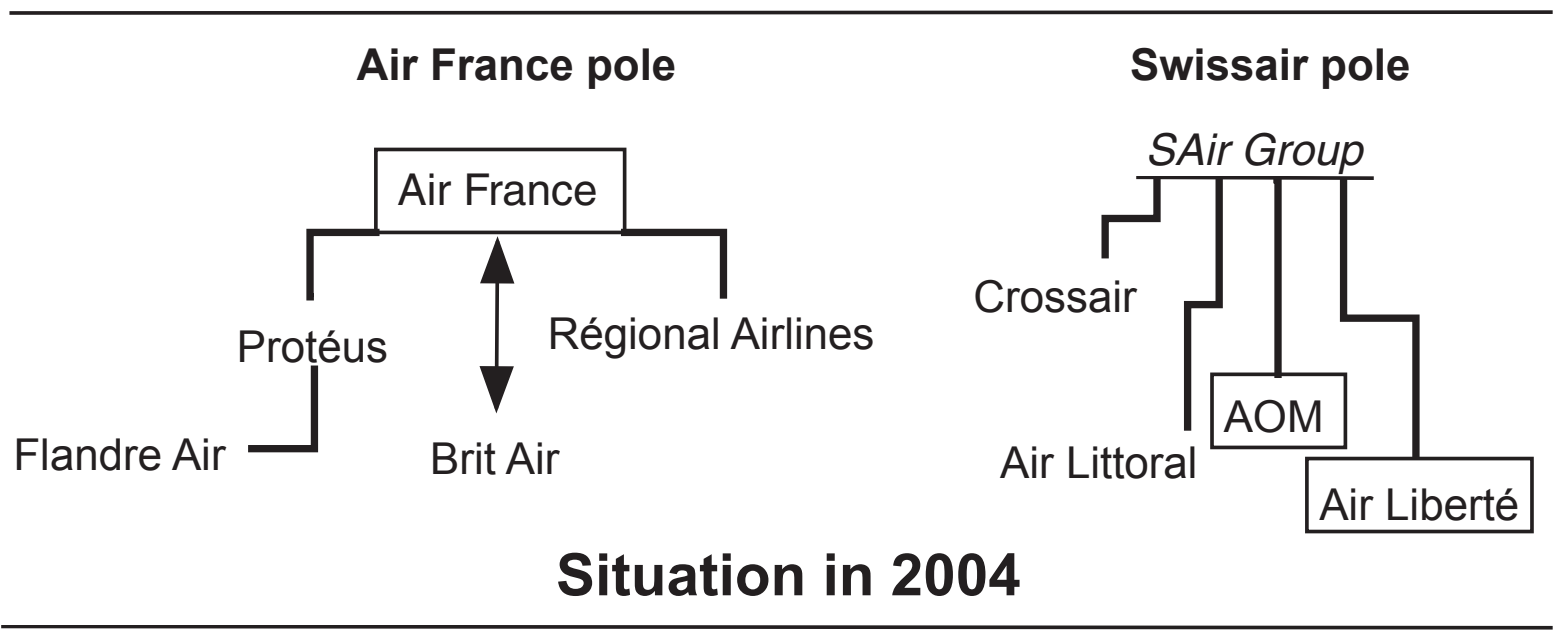

Air France pole

Other competitors

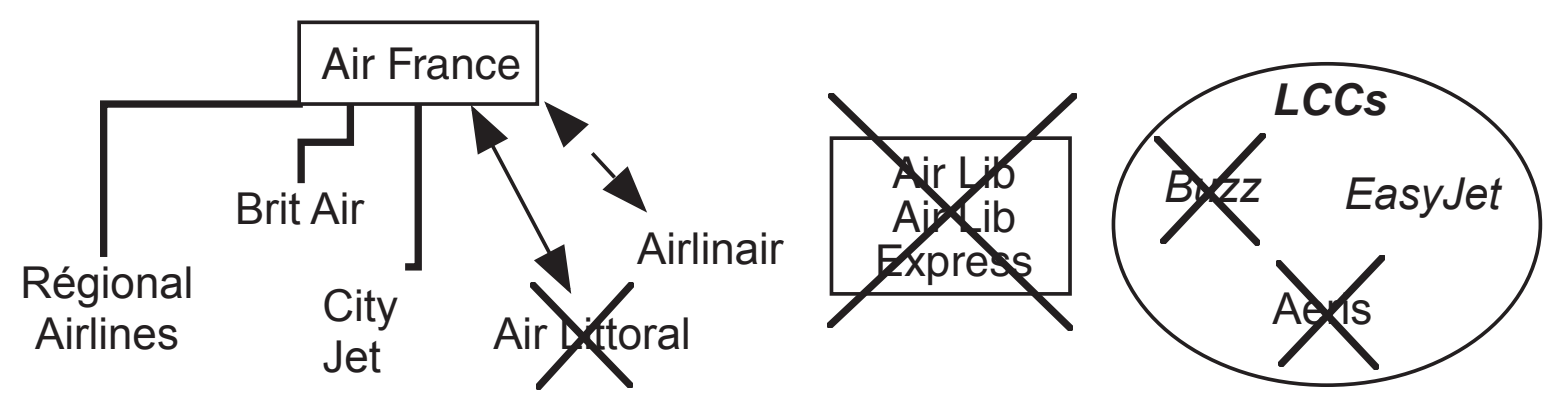

\begin{tabular}{|clll|}
\hline$B A$ & Foreign carrier & Ownership \\
\cline { 1 - 1 } & French carrier & $\longrightarrow$ & Franchise / charterizing \\
Brit Air & Regional carrier & - & Simple Partnership \\
\hline
\end{tabular}




\section{An appreciably increased accessibility for French regions}

The capitalistic intensive manoeuvres which have occurred between 1998 and 2002 complete a process of development of cross-country lines and régional hubs which has completely transformed in a very positive way the accessibility of many provincial towns, a little bit in contradiction with the initial forecasts. The very weak use of the Fund for equalization of air transport $\left(\mathrm{FPTA}^{7}\right)$, created in 1995 to allow the survival of the weakest lines compromised by the deregulation, constitutes an eloquent indicator of this unexpected evolution ${ }^{8}$. The French cities knew notable profits of accessibility, which we will endeavour to quantify.

\subsection{The new hubs : considerable windfall gains for the cities which accomodate them}

The French Civil Aviation Authority (DGAC) distinguished in 1998 six hubs on the national metropolitan territory (table 3 ).

Table 3 : The French hubs in 1998 (Sources : DGAC, 1999 and DGAC, 2000)

\begin{tabular}{|llrrrr|}
\hline \multicolumn{1}{|c}{ Airport } & \multicolumn{1}{c}{ Based carrier } & $\begin{array}{c}\text { Total } \\
\text { passengers } \\
\text { traffic 1998 } \\
\text { (in millions) }\end{array}$ & $\begin{array}{c}\text { Number of } \\
\text { flights (in- and } \\
\text { outbound) in } \\
1998\end{array}$ & $\begin{array}{c}\text { Market } \\
\text { share of the } \\
\text { based } \\
\text { carrier } \\
(1997)\end{array}$ & $\begin{array}{c}\text { Evolution } \\
\text { of } \\
\text { passengers } \\
\text { traffic } \\
1995 / 1998\end{array}$ \\
\hline \hline Paris CDG & Air France & 38,600 & 428537 & $49,8 \%$ & $+36,5 \%$ \\
Nice Côte d'Azur & Air Littoral & 8,086 & 204085 & $8 \%$ & $+31,3 \%$ \\
Lyon Satolas & Air France & 5,211 & 108374 & $40,4 \%$ & $+17,6 \%$ \\
Bâle Mulhouse & Crossair & 2,960 & 126052 & $31,7 \%$ & $+25,5 \%$ \\
Montpellier & Air Littoral & 1,533 & 102806 & $12,6 \%$ & $+24,2 \%$ \\
Clermont-Ferrand & Regional Airlines & 0,728 & 62741 & $45,6 \%$ & $+98,7 \%$ \\
Saint-Étienne & Proteus & 0,194 & 36877 & $14,2 \%$ & $+132,0 \%$ \\
\hline
\end{tabular}

They were obviously of varied sizes. It will be noticed that, except Air France in Paris CDG like in Lyon, and Regional Airlines in Clermont-Ferrand, the based carriers are very far from being prevalent in the traffic of their airport hub. That is due to the relative importance of the radial lines ensured by Air France: those are older and are served by middle-sized planes (of at least 100 places). The transverse lines of the new candidates are served almost exclusively by low capacity planes, with frequencies which seldom exceed 3 to 4 rotations per working day.

In terms of evolution, all the hubs had generated over three years growths expressed with two digits, even in the very particular case of Saint-Etienne, with three digits. It is however necessary to relativize the impact of the choice of Nice by Air Littoral on the growth of this platform, taking into account the modicity of its share of the total traffic $(8 \%)$. The largest part of the growth of the airport traffic is due to the opening of new lines by third parties, sometimes very aggressive commercially, like EasyJet (3 lines, 450000 passengers in 1998) which drains itself $50 \%$ of the Air Littoral passengers over the same period.

The structure of "hub and spoke" is intended to homogenize global flight times and the possibilities of connections from any point of network to any other one (connexity) while avoiding multiplying the direct flights whose filling would have been problématic (Varlet, 1997). Even if a stop is compulsory during the travel, the total time remains definitely lower than by train or by car. It is necessary to underline in the French case that, between regions or between any region and foreign countries, the compulsory stop has always been the rule with some rare exceptions, taking into account the radial structure of the Air Inter (then Air France) network. One can note that the connections on the two Parisian platforms require definitely more transit time than on smaller

\footnotetext{
${ }^{7}$ In French : Fonds de péréquation du transport aérien. This Fund is fed with a tax on all plane tickets sold in France (4 FRF - 0,61 EUR initially).

${ }^{8}$ Between 1995 and 1997 included, the boxed receipts were 330,4 million FRF (50,37 Mio EUR) while the expenses reached 190,9 million FRF (29,10 Mio EUR). This strong surplus led the government to reduce the level of taxation of the three quarters in two steps (1996 and 1997). In 1999, the annual expenditure for the support of the eligible lines was 51 million FRF (7,77 Mio EUR).
} 
airports. The structure of "hub and spokes" could be a solid sales point for provincial customers rejected by the wastes of time in Paris and a company like Regional Airlines did not failed to use this argument, thus popularizing a technical term up to that point only known by rare initiates.

De facto, it also develops the city which accomodates the hub, creating a considerable windfall effect ${ }^{9}$. If we focus on the case of Clermont-Ferrand, 19 French destinations and 6 European ones, served 2 to 3 times per day, were gradually offered, whereas before only one line towards Paris was in operation. In the case of platforms better served before like Nice, the windfall gain is less important insofar as the tourist attractivity of the French Riviera had justified the creation of several point to point domestic or European lines.

The progressive changing of scale of the networks concerning these platforms created the conditions of a real competition for middle- and long-range links. The passenger living apart from the Paris area have discovered real alternatives to the transit by the major hub of Air France (Roissy CDG). Certain competitors had this strategy, without inevitably being leaned with a large alien carrier. Thus, Regional Airlines, before its purchase by Air France, had concluded agreements with five large European airline companies, offering in fact up to five choices on intercontinental connections like Clermont-Ferrand - New York or La Rochelle - Rio. The fact that these same large European companies come to pick, themselves or through a « partner » regional carrier, passengers on certain large platforms could have provoked some nuisances to the national company : Nice dispatches for example 1 million annual passengers towards London and only 670 000 towards Paris CDG.

A more recent point shows that only four of these hubs are still surviving (Paris, Lyon, ClermontFerrand and Mulhouse). The reasons of this important rate of mortality will be explained further (4.1). Among these airports, Clermont-Ferrand is the one which benefitted the most from its promotion : reaching more than one million passengers in $2002(+27,9 \%$ compared to $2001,+45,6$ $\%$ compared to 1998), it became the 12th national airport. Two other régional hubs have been created in the meanwhile : Le Havre (Regional Airlines) and Bordeaux (the new « iberic gate » of Air France). Table 4 shows the traffic evolutions from 1998 to 2003.

Table 4 : Traffic evolution of the airports still beeing or having been regional hubs (source : UCCEGA, 2004)

\begin{tabular}{|c|c|c|c|c|c|c|c|c|c|}
\hline Air & $\begin{array}{l}\text { regional } \\
\text { created }\end{array}$ & $\begin{array}{c}\text { hub } \\
\text { by }\end{array}$ & $\begin{array}{l}\text { Hub still } \\
\text { in } \\
\text { operatios }\end{array}$ & $\begin{array}{c}\text { Traffic } \\
1998 \\
\text { (millions; }\end{array}$ & $\begin{array}{c}\text { Traffic } \\
1999 \\
\text { (millions') }\end{array}$ & $\begin{array}{c}\text { Traffic } \\
2000 \\
\text { (millions; }\end{array}$ & $\begin{array}{c}\text { traffic } \\
2001 \\
\text { (millions) }\end{array}$ & $\begin{array}{c}\text { Traffic } \\
2002 \\
\text { (millions;) }\end{array}$ & $\begin{array}{c}\text { Traffic } \\
2003 \\
\text { (millions: }\end{array}$ \\
\hline Vice & Air Littoral & & mo & 8.086 & 8,661 & 9,392 & 8.997 & 9,197 & 9.141 \\
\hline -yon & Air Fran & & yes & & & & & & \\
\hline Clerm & dRegio & & $s$ (AF) & 28 & & & & & \\
\hline use & & & yes ( & & & & & & \\
\hline 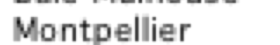 & $\mathrm{Ai}$ & & no & 1, & & & & & \\
\hline ain & Prote & & no & 0 , & & & & & \\
\hline & & & yes & & & & & & \\
\hline $\mathrm{Hz}$ & Regional & & yes (Air Jet) & & 0,139 & 0,118 & 0.06 & 0.05 & 0,0 \\
\hline
\end{tabular}

Last year of operation as a hub

First year of operation as a hub

\subsection{A generalized widening of the range of destinations initially offered by the great majority of the French airports}

If the development of régional hubs apart of Paris opens possibilities for the airports concerned, it modifies the global accessibility of many cities, touched by several networks which are partially competitors or complementary if they belong to the same group. The possibilities of relationship between provincial towns multiply overall in times definitely lower than those of the services of the French Railways (SNCF), as the two examples show it below (figure 2). In both cases, we can notice that Air France considerably increased his deterrent force by taking the control of Regional Airlines.

\footnotetext{
${ }^{9}$ Varlet, $1997.40 \%$ of the passengers of the Clermont-Ferrand hub are inhabitants of the Auvergne region.
} 
Figure 2 : two examples of the multiplication of possibilities of air transport between provincial towns (official timetables, summer 2003, working days)

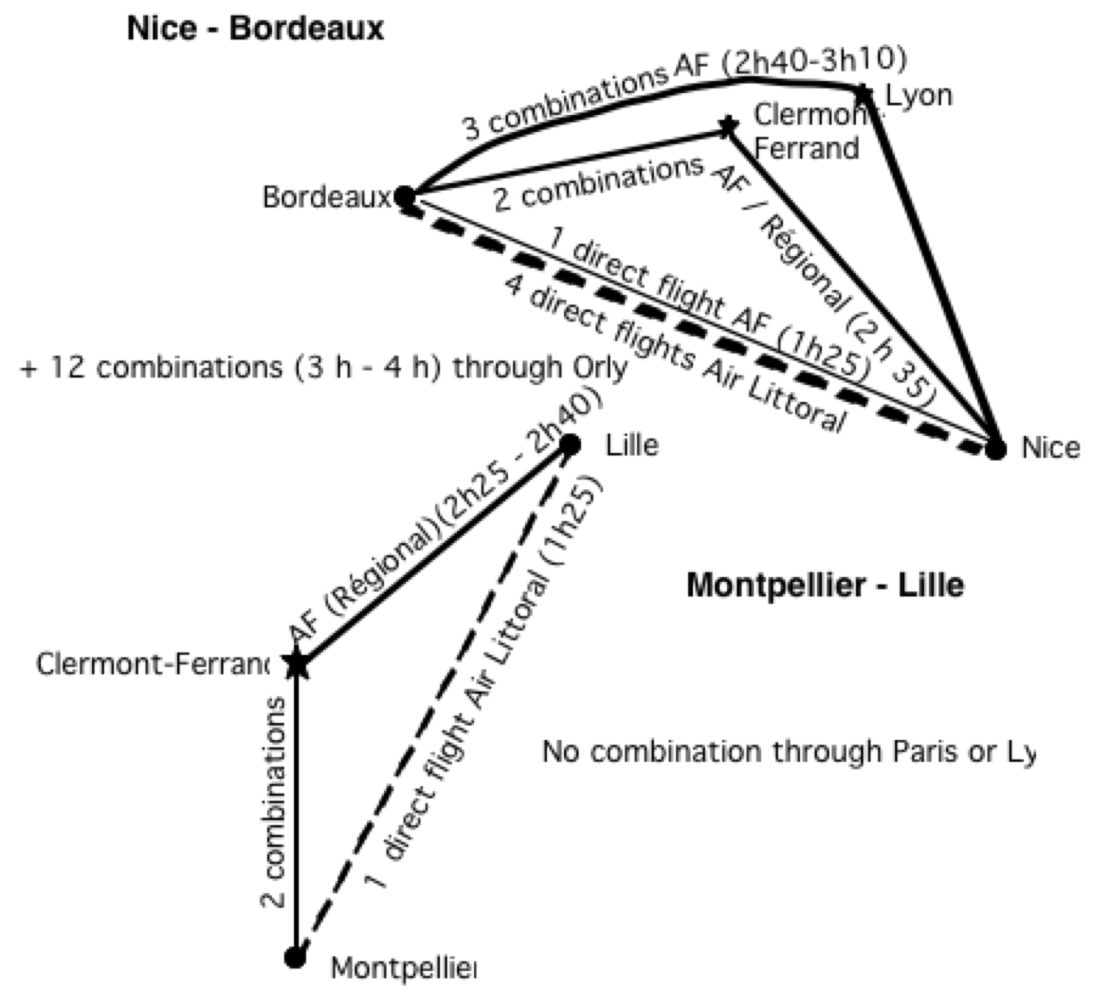

Even while remaining within the Air France nebula, many regional capitals saw the number of direct relations with other cities increasing considerably. That is in particular the case of Rennes from where daily leave (working days) 24 direct flights towards 11 different destinations, offered by two companies (figure 3). One could also quote the case of Bordeaux, promoted gateway of the Iberian peninsula from the French regions. 19 destinations are directly accessible, including 9 abroad. These mini-hubs were developed by Air France, which used the planes of its subsidiaires like Regional, Proteus or Brit Air to « explore » the new lines. 
Figure 3 : An example of opening of regional capital towards outside: Rennes (official timetables, summer 2003, direct flights only)

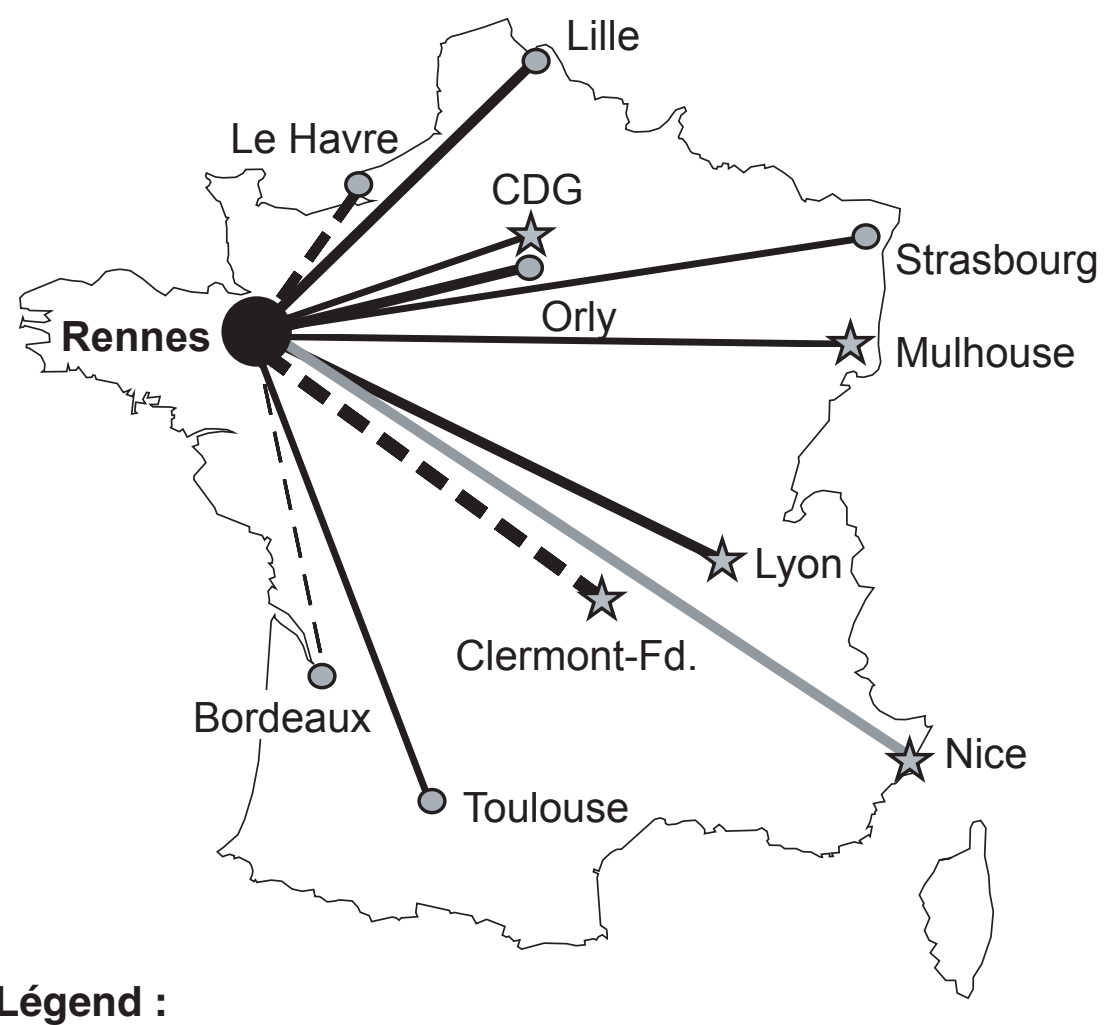

\section{Légend :}

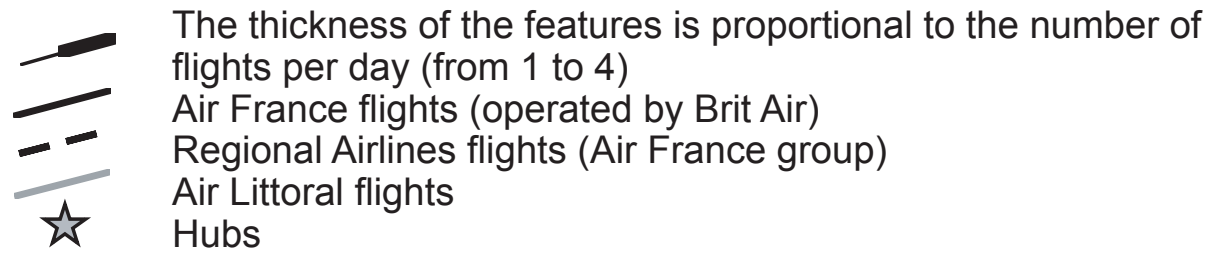

\subsection{The recent irruption of the Low cost carriers widens the range of destinations and opens small platforms to the international traffic}

This phenomenon is far from being marginal, insofar as it concerns an increasing number of airports and as the generated traffic increases in very strong proportions. A recent synthesis of the DGAC (DGAC, 2003) reports a progression of $85 \%$ between 2001 and 2002! From 1,285 million passengers in 1999 , the traffic jumped to 5,130 million passengers in 2002 , that is to say a multiplication by four.

So far, this phenomenon is the exclusive fact of foreign companies if we exclude the unachieved and suicidal incursion of Air Lib in 2002. In fact British Isles generate the large majority of the traffic $(58,9 \%)$, but their proportion drops regularly whereas other countries progress (Germany, Sweden, Belgium).

Taking into account the shortage of slots already evoked in the two major Parisian airports (Roissy CDG and Orly), Low cost carriers mainly invested regional airports, sometimes of very small size. They primarily created flights between French regions and foreign countries, taking part only in a very marginal way in the competition on the domestic flights ${ }^{10}:$ in 2002 , they transported only 283 000 passengers against 5,129 million passengers on international connections (DGAC, 2003).

\footnotetext{
${ }^{10}$ We could quote the very short attempt (a few months in 2002) of Buzz to create two transverse domestic lines between Quimper and Marseills on the one hand and Bordeaux and Grenoble on the other hand. Only EasyJet tries to
} 
Figure 4 : The French airports served by Buzz just before its purchase by Ryanair (2002)

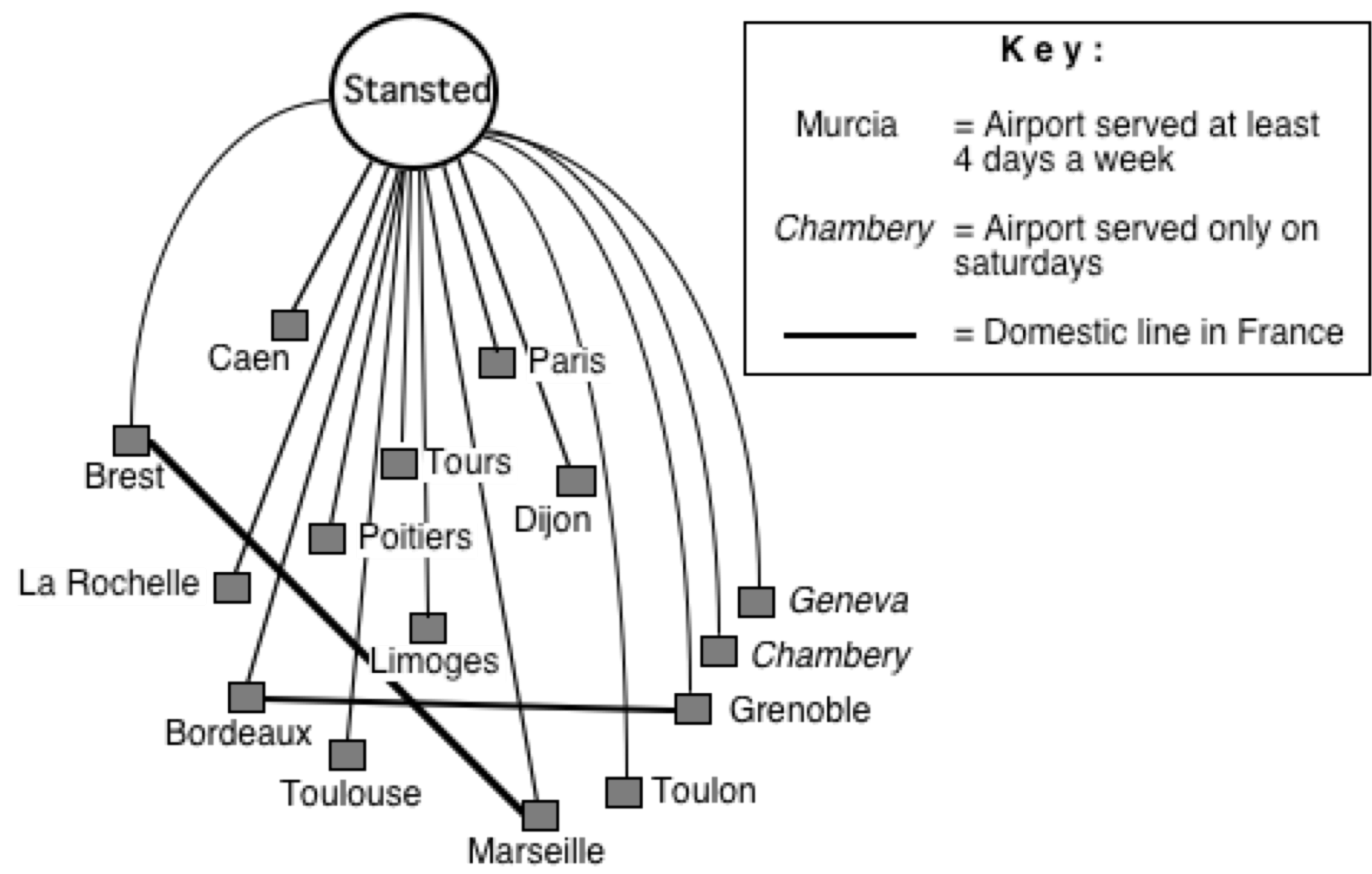

In 2002, the low cost carriers were servicing 28 French airports. Their traffic has a variable importance according to the size of the airport and the number of companies stopping in it. We propose the following typology based on their market share :

a- very weak market share on airports with high level of traffic: Paris CDG $(1,6 \%)$, Paris Orly $(0,9 \%)$, Lyon (1,2\%), Toulouse (1,1\%), Strasbourg (1,5\%), etc;

b- average market share on regional airports: Biarritz (14,8 \%), Caen (19,3\%), Limoges (24,6 $\%)$, Grenoble (27,6 \%), Rouen $(28,2 \%)$, etc;

c- prevailing market share on small airports: Beauvais $(90,5 \%)^{11}$, Carcassonne $(99,7 \%)$, Dinard $(76,3 \%)$, Bergerac $(77,9 \%)$, Tours $(90,5 \%)$, etc

d- average market share on airports with high level of traffic: it is the particular case of Nice, second French airport after Paris, where the share of Low cost carriers borders $20 \%$. Nice accomodates eight different ones. That would be explained by the tourist attraction of the French Riviera and by the absence of alternate airports in the vicinity : do the carriers have really the choice?

The chart of the services recuts that of the second homes of the British citizens in France with a clear prevalence of the western half of the territory: Brittany, Normandy, Touraine, Poitou, Périgord and the Aquitaine from now on are directly connected to London.

With rare exceptions, they are not very frequent services. For a French regional airport, a flight per day four to six days per week seems to be the standard level. Concerning the schedules, it is

compete with Air France on Paris - Nice and Paris - Marseille, but with a limited number of flights (4 rotations for each).

${ }^{11} 80 \mathrm{kms}$ far from Paris, Beauvais is the preferred parisian airport for Low cost carriers. 
those which arrange the company. Most of the outbound flights are positioned beyond 22 hour $^{12}$. From France, it's generally impossible to spend a whole day or even half a day at the destination.

We can temporarily consider that, in the current situation, the Low cost carriers are addressed first of all to foreign customers in the search of direct flights to lower cost. Competition with the « classical » companies will be frontal only if the low cost develop more domestic flights or services with strong frequency between large European cities.

\subsection{A more contrasted evolution of the services between Paris and other French towns}

Two periods must be dissociated between 1993 and 2003, with a hinge around 2000. During the first time, Air France, confronted with the rise of competition on its best lines, develops to the maximum its frequencies on them. In parallel, the rise in load of the intercontinental hub of Roissy CDG imposes an increase in the frequencies towards this last airport. The destinations concerned there thus gain doubly. After 2000, competition becomes less sharp (except that of the TGV) and a series of generalized crises strike air transport (attacks of September 11, 2001, war in Iraq, etc.) Air France reduces its network and redefines its frequencies selectively.

Focusing only on the evolution of the network Air France - Air Inter between 1993 and 2000, it is obvious (figure 5) that all the destinations of the metropolitan territory did not undergo the same evolutions of a quantitative nature. If the "millionaire" lines were particularly favourized with the introduction of at least hourly services under the commercial name "La Navette" (the Shuttle) and the intensification of the relations with Roissy, the number of flights for the other destinations evolved only very slightly. Three destinations (Grenoble, Tarbes and Saint-Etienne) preserve exactly the same number of services as in 1993. Nine cities are in addition still not directly connected to Roissy : Quimper, Béziers, Nimes, Tarbes, Avignon, Grenoble and the three Corsican airports.

No reduction in service is to be noted except for the wave of suppressions of 1996 which had touched Toulon, Perpignan and Nantes, largely compensated for the two formers by the arrival of AOM and Air Liberté.

On the lines where a competition remains, the total number of services increased considerably by cumulating the concurrent offers. Thus, on Paris (CDG and Orly) - Nice, not less than 48 daily flights (working days) were proposed in each direction, to compare with the 21 flights offered in 1993 by Air France and Air Inter. On Paris - Toulouse, the cumulated offer of Air France and Air Liberté was reaching under the same conditions 51 flights in each direction in 2000 against 19 flights in $1993^{13}$.

\footnotetext{
${ }^{12}$ Thus, the single daily flight departing from Clermont-Ferrand to London Stansted (Ryanair) takes off at 22. 15. The two daily departures of Ryanair from Montpellier are carried out at 21. 55 (Frankfurt Hahn) and 22. 20 (London Stansted). Schedules available in May 2003.

${ }^{13}$ Source : Website http://www.adp.fr/. Request on the flights of Thursday September 14, 2000 in both cases.
} 
Figure 5 : Evolution of the radial routes of the Air France group between 1993 and 2000 (sources: official schedules)

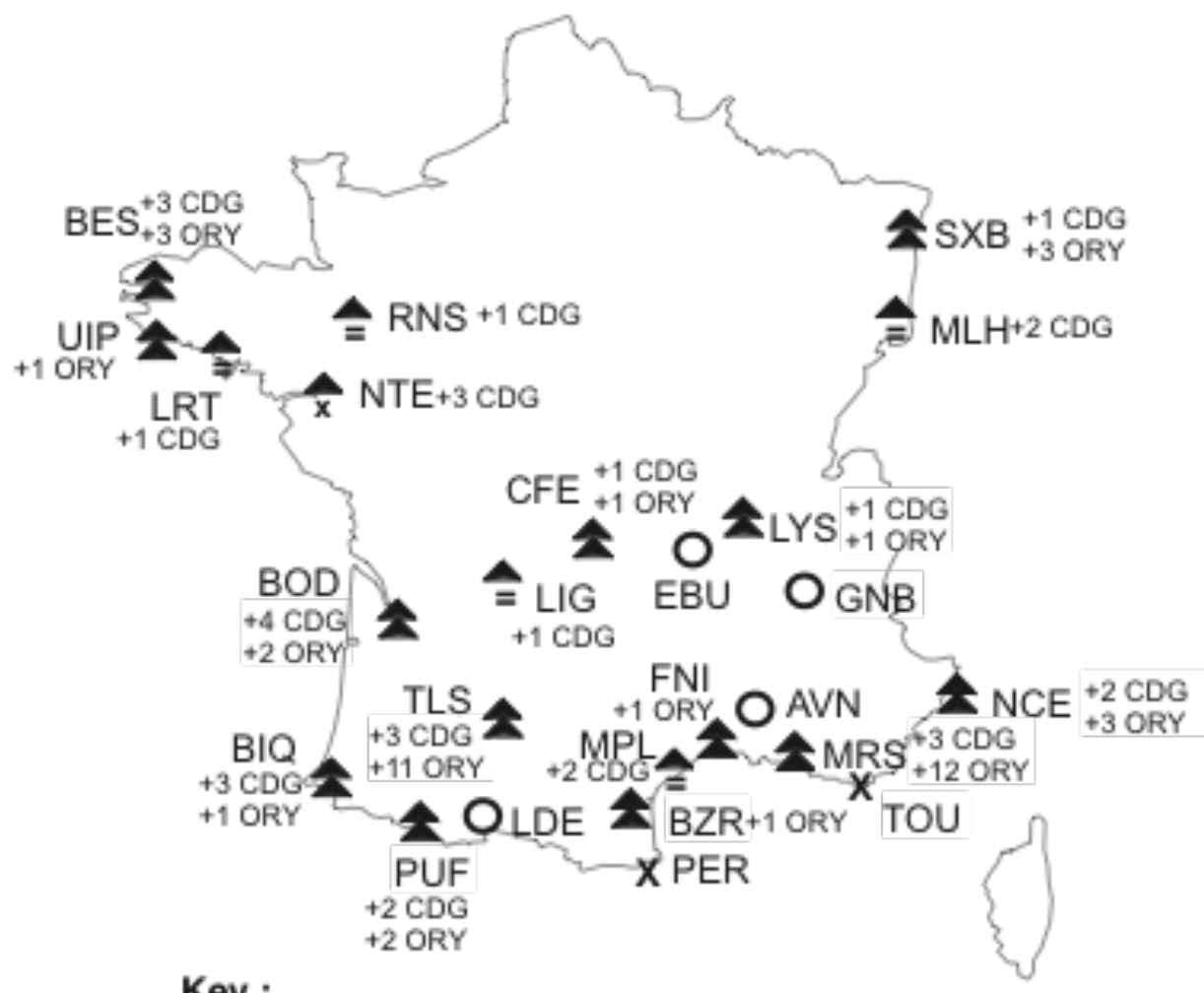

Key :

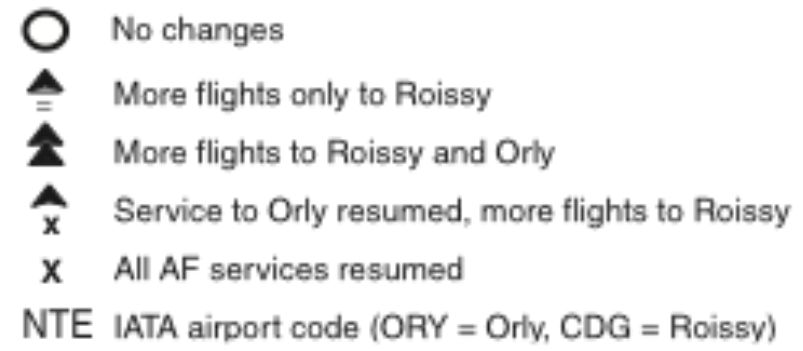

The second period which begins in 2000 sees significant falls of the radial offer intervening in a progressive way, as well because of the policy of Air France as of the withdrawal of its competitors. Thus, the disappearance of Air Lib at the beginning of 2003 brings back the total number of movements between Paris and Nice to 31 flights, which creates a situation of shortage considered to be unacceptable by the local economic actors (the possibilities of travelling at reduced price were singularly reduced). The situation develops in a comparable way between Paris and Toulouse, the 51 flights of 2000 being reduced to 32 flights in 2003. Air France on the other hand has replaced Air Lib on the lines to Toulon and Perpignan.

The crises which concern air transport in general contribute for their part to reductions of Air France offer. A certain number of airports are not served any more by the national company: SaintEtienne, Nimes, Béziers, Tarbes/Lourdes, Chambéry. The services are recovered in the majority of the cases by small companies like Air Jet, Air Atlantique or Airlinair, but with lower frequencies ( 2 rotations per day in general). It is easy to understand the interest which these forsaken airports carry to the arrival of Low cost carriers...

The opening of a new high speed railway line between Valence and Marseille (TGV Mediterranée) in June 2001 is also the occasion to reduce in a selective way the frequencies. Marseille is thus the 
airport which loses the most services of this fact with simultaneously the withdrawal of Air Lib and the reduction of the offer of Air France which passes from 33 to 24 daily flights. It is within this framework that the already evoked closures of the lines from Paris to Nimes and Béziers occur.

Finally, the offer remains overall higher than what it was in 1993, but definitely lower than that it could be between 1996 and 2000. The radial lines knew a golden age with competition. The return to the monopoly penalize them...

\section{A not yet stabilized situation}

We can now give an account of the main tendencies in terms of accessibility changes. It is however not certain that such a developed offer really corresponds to the needs, and the ongoing concentration of operators will result inevitably in the short and medium term in reorganizations of networks aiming at avoiding as much as possible redundancies, sources of costs a priori unacceptable in a competing context.

\subsection{The first régional hubs closures : Saint-Etienne, Nice and Montpellier}

The fate of Saint-Étienne is revealing difficulty in making cohabit competing hubs within the same group of airlines. This node had been created in the second half of 1997 by the regional company Proteus, under conditions and with goals comparable with those of the installation of Regional Airlines in Clermont-Ferrand. Upon the opening, 11 lines were operated from Saint-Etienne Bouthéon, with two daily frequencies in each direction ${ }^{14}$. Even if transported volumes were modest compared with others hubs, this opening made it possible the young company to multiply its customers by four between 1996 and 1997. The airport for its part gained $25 \%$ more passengers and $33 \%$ additional movements in the same lapse of time.

This success story does not fail to interest large foreign companies and, as of the end of 1997 , Proteus sees $34 \%$ of its shares purchased by Delta Air Lines. Delta gives to Proteus the slots it releases in Orly at the time of its transfer to Roissy. In parallel, Proteus increases its dependence viz. Air France by multiplying the franchized lines, which makes say to its chairman Franklin Devaux, interviewed by La Vie du Rail in May 1998, that 7 of the 18 planes of the fleet fly on behalf of Air France. In 1998, the hub of Saint-Etienne is directly connected to 12 destinations and 14 are scheduled for the first quarter 1999. It also opens to the international scale with the arrival of the low cost carrier Ryanair. The engineering departments and the maintenance of Proteus are transferred the same year from Lyon Satolas to Saint-Etienne, while the manager of the airport undertakes work of extension and modernization for 26,5 million francs (4,04 Mio EUR).

The bringing together between Delta and Air France, which create their Alliance (Skyteam) during 1999, as well as the faster development of the hub of Lyon by the national company create the conditions of an abandonment of the node of Saint-Etienne. In compensation, Proteus is franchized on new cross-country lines from Lyon, Marseille and Toulouse. All is accomplished on October 31,1999 . Only the activity of maintenance remains on the airport of Saint-Etienne. It is a hard blow for the airport which roughly loses 12 connections and 25000 annual passengers (that is to say approximately $13 \%$ of the traffic of 1998), without any alternative solution. On the other hand, it is not at all an obstacle for the development of the Proteus company whose 1999 turnover exceeds a billion francs (about 150 Millions $€$ ), and whose fleet grows from 42 to 65 planes. The establishment during two years on the airport of Saint-Etienne thus constituted an appreciable springboard for the development of the operator, without the creation of indissociable links.

In 2003, the former hub of Saint-Etienne is served only by three daily flights. Two rotations towards Paris are offered by Air Jet, small company with random financial health. The third rotation serves London Stansted (Ryanair).

The cases of Nice and Montpellier have been linked to the evolution of Air Littoral. These peripheral nodes were operating at the scale of the western part of the Mediterranean Basin, with

\footnotetext{
${ }^{14}$ Lille, Nantes, Bordeaux, Toulouse, Perpignan, Avignon, Nice, Chambéry, Annecy, Strasbourg and Reims. Proteus also operated six franchized lines for Air France from Paris, Lyon and Marseille, and some interrégional lines for its own account (Lorient - Lyon, Nantes - Pau, etc).
} 
links to Spain, Italy and Corsica. During the last year of operation (2003), Montpellier was directly connected to 9 destinations, while Nice was linked with 14 other cities. The disappearance of Air Littoral generates more disagreements for Montpellier than for Nice. The latter can rely on the demographic weight (about 1 million inhabitants) and the dynamism of the whole French Riviera : Air Littoral has been rapidly replaced by other carriers...

\subsection{Could other hubs disappear?}

It seems obvious that the recombining of various nebulas of operators creates new situations of redundancy. One is quite naturally tempted to ask the question of the future of the hub of ClermontFerrand, following the purchase by Air France of Regional Airlines in January 2000. The last independent carrier which had, as we saw before, tried hardly not to depend on a large actor on the market, thus entered the the national carrier group. Can its central hub, direct rival of Lyon, be maintained for a long time?

For the moment, Clermont-Ferrand does not seem to be condemned. We can notice, by questioning the Web site of Air France ${ }^{15}$, that the transit through this hub still appears in the list of proposals for a routing between provincial towns as well as Lyon, and that all the Regional flights have received a AF flight number. We can put forward the assumption of a better effectiveness of the airport of Clermont-Ferrand, recently reorganized around the exchange between Regional Airlines flights, which makes it possible to consider transit times ranging between 25 and 45 minutes, while the Lyon Satolas airport imposes connection times ranging between 45 minutes and 1h10, according to whether or not there would be a change of terminal. If it is the case, any evolution of the Lyon hub towards more effectiveness could put at evil current balance.

Regional Airlines even seems to constitute for Air France an agent of development of new secondary hubs insome regional capitals. It is the case of Bordeaux, which is reinforced since October 2000 by the addition of new destinations. All the interregional or international lines, new or preexistent, are operated under the label Air France by its new subsidiary company. On the other hand, Regional ceases the exploitation of its secondary hub of Le Havre, which was especially used to feed, from a great French north-western quarter, the network of KLM via Amsterdam. This small hub has been taken again by Air Jet which ensures two daily rotations per working day towards four destinations (Toulouse, Amsterdam, Brussels and Nantes), Air France in parallel offers two daily flights towards Lyon. The current difficulties of Air Jet, which filed for bankruptcy in May 2003, make again arise the question of the perennity of the small hub of Le Havre.

\subsection{An actor up to that point discrete: the French railways (SNCF)}

Against its will, the SNCF was projected in the fight for the maintenance or the profit of market shares engaged by the competitors of the French sky. The «millionaire » lines initially concerned were lines where the rail services did not make save time significantly, compared to te plane. Thus, only the tariffs and the frequency could make the difference. With the exception of the Paris Toulouse line ; and this for a short period (1995-1996), the SNCF tariffs were always lower than those of air competitors. On the other hand, the significant increase in the air frequencies determined modal transfers of travellers, primarily for business purposes. The increase in the quality of service in air transport also could have been significant for this same category. So the SNCF lost market shares, in particular on its services from Paris to Nice, Marseille, Strasbourg and Toulouse.

But the national railways company did not say its last word on the connections served by TGV. It is out of attack on destinations like Lyon or Nantes, which in addition profited from a clocking of the service roads per hour or half an hour. The prolongation of the high speed line to Marseille in June 2001 logically brought profits of market share for the railroad on this destination as on Avignon, Nimes and Montpellier, to the detriment of the Air industry. Air Lib had given up its flights on Marseille as of the acceleration of the TGV, and Air France substantially reduced the frequency of its «shuttle » Orly - Marseille. The train remains very competitive on interrégional relations at high speed like Lille- Lyon where prices and frequency are combined. Competition is

\footnotetext{
${ }^{15}$ http://www .airfrance.fr/
} 
thus wild on a certain number of lines, and it does not turn inevitably to the advantage of the airlines.

An area of agreement between rail and air can be also found for the feedering of the hubs having a high speed rail station (Lyon Satolas, Paris CDG) by train. After limited attempts like the pre routing under flight number AF of air travellers from Lille to Roissy since 1995, the SNCF and Air France passed higher speed while proposing in September 1999, under the commercial name $T G V^{\prime}$ Air, attractives tariff and time combinations from a half-dozen of relatively close towns even from abroad (Lyon Part-Dieu, Poitiers, Tours, Mans, Angers and Brussels). In this case, the railway company plays a role of feeder as well as an airline chartered or franchized by a major carrier. There are however no exclusive bonds : the SNCF also made a deal with United Airlines. This carrier offers preferential rates to the holders of the SNCF 12-25 years card. For the moment, the national company refuses to engage in a total alliance which would profit from the exclusiveness in the efforts in feedering.

Up to that point, the agreement was easy to obtain because it concernes connections on which the SNCF does not compete directly with domestic air transport ${ }^{16}$. The saturation of the Parisian airports, principal cause of the weak development of competition on the radial lines, could lead one of the candidates to develop a narrower partnership with the owner of the TGV ${ }^{17}$. That would enable it to enlarge its offer, and particularly to reach in Roissy where the competitors of Air France do not have for the moment been able to settle.

\section{Conclusions}

For the moment, we can break up the events which have occurred since 1995 into four phases:

a- a tariff and/or services war on a limited number of main radial lines, which ends in the durable installation of two new relatively weak competitors ${ }^{18}$ (AOM, Air Liberté) and the maintenance of Air France, supported by the detention of a great majority of the slots on saturated Parisian platforms. The situation is stabilized from 1997 on this basis;

b- a flowering of regional hubs centered (Clermont-Ferrand, Saint-Etienne, Lyon) or peripheral (Nice, Montpellier, Le Havre, etc.) multiplying the possibilities of cross-country connections and allowing the emergence of a real competition on these connections. This movement begins from the first half of the1990's and the last development of hub announced in 1999 relates to Bordeaux (Air France);

c- a recombining among competitors which leads to a duopoly and which should have led logically to a simplification of the networks and a reduction in the number of hubs. But the premature bankruptcy of Swissair in 2001 stops this movement. Air Lib (Air Liberté + AOM) struggles for life but is locked up in choices which can only lead to bankruptcy, intervened at the beginning of 2003. Air Littoral recovers its independance but suffers from a permanent lack of own capital stocks. The carrier is for sale during the autumn 2003, and finally disappear in december 2003.

d- Since January 2003, the radial routes are travelled only by planes of the group Air France, subjected to a very symbolic competition of some Low cost carriers. A slight competition on the main routes has been relaunched with Aeris ${ }^{19}$ and Easyjet, but the two companies did not recover the half of the slots of the late Air Lib in Paris-Orly ${ }^{20}$. The disappearance of Aeris in october 2003

\footnotetext{
${ }^{16}$ Except for the CDG - Lyon Satolas line.

${ }^{17}$ It would repeat what Lufthansa had carried out with the Deutsche Bahn at the beginning of the years 1980: the freighting of complete trainsets between two stations of airports (Frankfurt - Cologne) in order to recover useful slots for long- and middle-range links.

${ }^{18}$ The brittleness of the situations of the unit TAT/Air Liberté and AOM had allowed then the entry in their capital of large foreign carriers.

${ }^{19}$ Aeris could be considered as the first real French Low cost carrier.

${ }^{20}$ In March 2003, the two challengers obtained 14912 of the 44528 slots left vacant by the disappearance of Air Lib (33,49\%): 7612 slots for Aéris, 7300 for Easyjet. A third candidate, Virgin Express, obtained 5840 slots, which must enable him to ensure three daily rotations to Bordeaux and two rotations to Toulon. This attribution does not create the conditions of a dangerous competition for Air France.
} 
leaves EasyJet singularly alone face to the flag carrier. One can thus consider that Air France will control its domestic market durably, the place left to its competitors hardly giving them room for manoeuvre.

However, we can consider that never the opening towards the outside of the various French regions will not have been also large, because of the multiplication, not called into question, of the point to point interrégional connections. In that, the deregulation of air transport will have more made for the regional planning than all the policies of support followed before, which especially aimed at connecting a few businessmen to the Parisian decisional center.

\section{Bibliography ${ }^{21}$}

Assemblée nationale, 1999. Commission de la production et des échanges, Avis sur le projet de loi de finances pour 2000 ( $n^{\circ}$ 1805), Équipement, Transports et Logement, Transports aériens, Paris, Journaux officiels, october 14th, 31 p (@).

Bootsma (P.D.), 1997. Airline Flight Schedule Development ; analysis and design Tools for European Hinterland Hubs, Utrecht, Elinkwijk.

Button, (Kenneth) (ed.), 1991. Airline Deregulation: International Experiences, New York: New York University Press, 191p.

Cederlund (Kerstin)(ed.), 2003. New trends in the European Air Traffic, Rapporter och Notiser 164, Lund University, 157 p.

Dupéron (Olivier)(dir.), 1998. Les nouvelles conditions de la desserte aérienne du territoire, Rapport final, Reims, CRDT URA CNRS D1479, june, 105 p (@).

DGAC, Direction de la navigation aérienne, 1999. Rapport d'activité 1998, Paris, 48 p (@).

DGAC, Service des bases aériennes, Activité des aéroports français, annual edition (@).

DGAC, Service des bases aériennes, 1999. Note sur les " hub and spoke » ou réseaux en étoile, Paris,11p(@).

DGAC, Direction des transports aériens, 2003. L'envolée des compagnies à bas-coûts en France, Note de synthèse et d'actualité $\mathrm{n}^{\circ} 11$, february, 5 p. (@).

Espérou (Robert), Subrémon (Alexandra), 1997. La politique communautaire du transport aérien, Paris, P.U.F., 128 p.

Gaudry (Marc) et Mayes (Robert R.)(dir.), 1999. La libéralisation du transport aérien, bilan et perspectives, Paris, Institut du transport aérien, 248 pages.

Martre (Henri), 1998. La desserte aérienne au service du développement territorial, Paris, La Documentation française, coll. Rapports officiels, 32 pages (@).

Naveau (Jacques), 1992. Droit aérien européen, les nouvelles régles du jeu, Paris, Institut du transport aérien, $326 \mathrm{p}$.

Naveau (Jacques), 1999. Les alliances entre compagnies aériennes ; Aspects juridiques et conséquences sur l'organisation du secteur, Paris, Institut du transport aérien, october, volume 49, $69 \mathrm{p}$.

O'Kelly (Morton E.), 1998. « A geographer's analysis of hub-and-spoke networks », Journal of Transport Geography, Vol. 6, n 3, p. 171-186.

\footnotetext{
${ }^{21}$ The symbol@ at the end of the reference announces the documents reachable on line.
} 
Oum (Tae Hoon), Stanury (W.T.) \& Tretheway (Michael), 1990. « Airline deregulation in Canada and its économic effects » in Hayashi (T.)(ed.), New dimensions for Public utilities, Osaka, Osaka University Press.

Pavaux (Jacques), 1995. Le transport aérien à l'horizon 2020, Paris, Institut du transport aérien, 234 p.

Varlet (Jean), 1997. «La déréglementation du transport aérien et ses conséquences sur les réseaux et sur les aéroports », Annales de Géographie, n 594-595 (january-april).

Zembri (Pierre), 2000. «Les premiers effets spatiaux des recompositions de réseaux aériens en France : des effets d'aubaine fragiles mais une réelle ouverture de nombreuses régions françaises », Flux, n ${ }^{\circ}$, p. 28-40. 